\title{
Trik Konselor Sebaya dalam Upaya Mencegah Perilaku Seks Pranikah di Kalangan Remaja
}

\author{
Muhammad Sayyid Naufal Ramadhan', Mohammad Salehudin'2, "Rudy Hadi Kusuma ${ }^{3}$ \\ 1,2,3 Institut Agama Islam Negeri Samarinda, Indonesia \\ *rudi.hadi@iain-samarinda.ac.id (Corresponding Author)
}

\begin{tabular}{|c|c|}
\hline (A) Check for updates open $\partial$ access cc (i) & DOI: https://doi.org/10.53621/jider.v1i1.16 \\
\hline Informasi Artikel & ABSTRAK \\
\hline $\begin{array}{l}\text { Riwayat Artikel: } \\
\text { Diterima: } 22 \text { Agustus } 2021 \\
\text { Revisi Akhir: } 25 \text { Agustus } 2021 \\
\text { Disetujui: } 25 \text { Agustus } 2021 \\
\text { Terbit: } 25 \text { Agustus } 2021\end{array}$ & $\begin{array}{l}\text { Tujuan penelitian ini untuk mendeskripsikan trik konselor sebaya dalam } \\
\text { upaya mencegah perilaku seks pranikah di kalangan remaja, penelitian ini } \\
\text { dengan pendekatan kualitatif deskriptif memilih lokasi penelitian dan } \\
\text { konselor sebaya yang berada di empat PIK-R (PIK-R Widiagama, PIK-R } \\
\text { Palapa, PIK-R Mahakam Borneo dan PIK-R Pelita Hati di Kota Samarinda) }\end{array}$ \\
\hline $\begin{array}{l}\text { Kata Kunci: } \\
\text { Trik konselor sebaya, } \\
\text { Upaya Mencegah Perilaku Seks } \\
\text { pranikah, } \\
\text { Kalangan Remaja }\end{array}$ & $\begin{array}{l}\text { wawancara digunakan untuk mengumpulkan data dengan model } \\
\text { wawancara terstruktur kemudian di analisis dengan model miles and } \\
\text { Huberman. Hasil penelitian pada upaya yang dilakukan beberapa trik } \\
\text { konselor Sebaya bersama PIK-R dalam upaya mencegah perilaku seks } \\
\text { pranikah yaitu diantaranya; 1) Trik dengan Penyuluhan oleh konselor sebaya }\end{array}$ \\
\hline ats & $\begin{array}{l}\text { ke lingkungan remaja dan ke sekolah-sekolah, } 2 \text { ) Trik dengan Penguatan PIK- } \\
\mathrm{R} \text { (pemberian pemahaman dan pembinaan) pemahaman kepada anggota } \\
\text { PIK-R melalui sharing materi dan diskusi serta pembinaan kepada PIK-R } \\
\text { yang baru dibentuk, 3) Trik dengan Sosialisasi Kepada Remaja 4). Trik } \\
\text { dengan sosialisasi kepada orang tua 5). Trik Memanfaatkan Media Sosial } \\
\text { dalam kampanye dan dokumentasi, dan 6). Trik Penyuluhan dan Sosialisasi. } \\
\text { Terjun langsung ke lingkungan remaja dengan media GenRe KIT dan } \\
\text { melakukan sosialisasi kepada orang tua remaja dan bekerjasama dengan BKR } \\
\text { (Bina Keluarga Remaja). }\end{array}$ \\
\hline
\end{tabular}

\section{PENDAHULUAN}

Perilaku seks pranikah atau dengan istilah lain adalah seks bebas dimaknai dengan sebuah perilaku seseorang yang melakukan hubungan seks diluar dari ikatan pernikahan, dan sangat risiko hubungan seksual pranikah (Lestari et al., 2014). Seks pranikah adalah perilaku dimana seseorang melakukan hubungan seks dengan lawan jenis dengan tidak adanya keterpaksaan yang dilakukan dengan ada atau tidak adanya ikatan hubungan berpacaran. Seks bebas dilakukan dengan cara bergonta ganti pasangan karena itu disebut "seks" seseorang yang melakukan seks dan "bebas" artinya siapa saja dan dimana saja (Darmawan, 2018). Kegiatan seks pranikah atau seks bebas adalah perilaku menyimpang yang banyak terjadi dikalangan remaja. Seks bebas adalah perilaku yang sangat beresiko terjangkit inveksi menular seksual (IMS) dan kehamilan dini yang tidak diinginkan, perlu penyuluhan pengetahuan dasar HIV dan AIDS (Syahputra, 2015).

Maraknya terjadi seks pranikah dikalangan remaja begitu memperihatinkan. Survei yang dilakukan tahun 2007 menunjukan bahwa 25\% - 51\% remaja telah melakukan hubungan seks pranikah. Sebesar 6,4\% remaja laki-laki dan 1,3\% remaja perempuan pernah melakukan seks pranikah menurut hasil survei Kesehatan Reproduksi Remaja Indonesia (KRRI). aborsi yang dilakukan remaja, pernikahan dini dan bahaya infeksi menular seksual (IMS) pada remaja (Rosdarni et al., 2015). Hal ini sangat miris sekali, dimana perilaku seks yang harusnya adalah dimaknai kegiatan yang dilakukan oleh sepasang suami istri, saat ini malah menjadi perilaku yang banyak dilakukan dikalangan remaja. Banyak hal yang menjadi faktor terjadinya perilaku seks pranikah dikalangan remaja, mulai dari aktifitas pacaran yang tidak sehat, pergaulan bebas, media sosial, akses atau konten-konten yang berbau pornografi di media sosial, dan pernah 
melakukan perilaku seksual dalam bentuk tertentu. Dari 300 mahasiswa, diketahui $86,7 \%$ pernah berpegangan tangan, 78,7\% berpelukan, 74\% mencium pipi dan kening, 58,7\% berciuman bibir, $23 \%$ memegang daerah sensitif, $14 \%$ mencumbu daerah sensitif, $6,67 \%$ petting, $2,67 \%$ oral seks, 2,67\% intercourse (Lestari et al., 2014). faktor yang mempengaruhi perilaku seksual pranikah siswa di STIKes Medistra Indonesia termasuk karakter, konsep diri dan sikap (Irmawaty, 2013). Seks pranikah saat ini sudah menjadi trend atau kebiasaan yang biasa dilakukan oleh remaja dalam perilaku berpacaran, seseorang yang tidak berpacaran pun bisa melakukan perilaku tersebut asal disertai ketidak paksaan dikedua pihak (Rohmah et al., 2015).

Melihat permasalahan diatas perlunya sebuah startegi untuk mengatasi masalah tersebut dan tidak ingin fenomena dan dampak buruk yang terjadi terus meluas dikalangan remaja pemerintah membuat sebuah strategi yang bekerja sama dengan BKKBN untuk mengatasi permasalahan tersebut, Keberadaan dan peranan PIK $\mathrm{R}$ dilingkungan remaja sangat penting (Fatmariza, 2019).

Pemerintah bersama BKKBN membentuk sebuah program untuk generasi remaja yang disebut GenRe (Generasi Berencana). GenRe adalah program yang dikembangkan dalam upaya mempersiapkan kehidupan berkeluarga bagi remaja, bekal remaja mampu menjadi pendidik sebaya dan menjadi agen perubahan bagi remaja dengan pengetahuan yang diperoleh kepada remaja lain melalui program PIK-R (Wibowo et al., 2020). Tujuan dari banyak program yang dilakukan pemerintah melalui BKKBN ini adalah meingkatkan kualitas hidup remaja dengan memberikan edukasi dalam hal menghindari beragam perilaku beresiko untuk kesehatan reproduksi sebagai seorang remaja, Analisis SWOT PIK-R menunjukkan bahwa kekuatan yang dimiliki program tersebut dari sisi sumber daya manusia, upaya integtatif dengan masyarakat, jenis layananya (Nurochim, 2021). BKKBN mengkategorikan resiko-resiko yang dihadapi oleh remaja diantaranya ialah TRIAD KRR, Tri (tiga) ancaman dini Kesehatan Reproduksi Remaja yaitu Seks bebas atau Seks Pranikah, HIV/AIDS dan NAPZA.

Diantara sasaran tersebut adalah kampus, sekolah-sekolah, Salah satunya dengan menghadirkan organisasi Pusat Informasi Konseling Remaja (PIK-R) (Budiyono \& Faishol, 2020) disetiap sekolah dan kampus-kampus yang ada di Indonesia. Pusat Informasi Konseling Remaja itu sendiri adalah sebuah program kerja dari BKKBN. Pusat Informasi Konseling-Remaja (PIK$\mathrm{R}$ ) ialah yang menjadi wadah dan dikelola dari, untuk dan bagi remaja dalam upaya memberikan layanan informasi dan konseling dan kegiatan-kegiatan penunjang lainnya (Nursal et al., 2020; Silfiana \& Setyowati, 2017), pemanfaatan PIK-R adalah dukungan teman sebaya. Tingkat pengetahuan, sikap, motivasi, dukungan guru serta dukungan teman sebaya memiliki hubungan yang signifikan dengan pemanfaatan PIK-R oleh remaja dengan variabel yang paling mempengaruhi yaitu dukungan teman sebaya (Nursal et al., 2020).

Konselor sebaya adalah para remaja yang memiliki tugas sebagai konselor sebaya, sebagai salah satu mitra petugas kesehatan (Kurwiyah, 2019), memiliki kriteria menjadi konselor sebaya bisa menjadi salah satu personel yang dipandang sangat tepat sebagai tokoh yang berperan aktif mengatasi berbagai masalah yang dialami kalangan remaja(Trisnani \& Wardani, 2018), konselor sebaya dapat melalui pembentukan dan pelatihan konselor sebaya, dapat menjadi suatu pilihan yang tepat dalam upaya membentengi anak atau remaja dari pengaruh negative lingkungan. Hal ini juga yang diterapkan oleh dinas pendidikan kota Surabaya yang mana berhasil menekan dan menanggulangi perilaku menyimpang siswanya (Sarmin, 2017). Termasuk masalah seks pranikah (Yudia et al., 2018) atau seks bebas di kalangan remaja yang dapat ditangani secara aktif dan persuasif oleh konselor sebaya, meningkatkan kapasitas konselor sebaya sehingga pelaksanaan konseling sebaya dapat meningkatkan ketahanan remaja dalam menghadapi permasalahan dan perilaku yang berisiko dapat dicegah (Kusumawaty et al., 2020). Salah satu upaya untuk menurunkan perilaku seksual pranikah dengan memberikan intervensi khusus pada remaja yang mengkonsumsi alkohol dan pengguna NAPZA (Suparmi \& Isfandari, 2016).

Dengan banyaknya penelitian yang membahas tentang perilaku seks dikalangan remaja tersebut, maka penelitian ini menarik dilakukan terhadap trik dan upaya konselor sebaya dalam melakukan berbagai aktivitas positif dilingkunganya yakni mencegah perilaku seks pranikah 
dikalangan remaja, semuanya dari remaja oleh remaja dan untuk remaja. Pertanyaan kunci dalam penelitian ini adalah bagaimana trik dan cara upaya konselor sebaya dalam mencegah perilaku seks pranikah dikalangan remaja? Sekaligus untuk menjawab tujuan penelitian ini.

\section{METODE PENELITIAN}

Penelitian ini menggunakan pendekatan kualitatif deskriptif (Sugiono, 2010). Penelitian kualitatif bertujuan untuk memahami suatu fenomena-fenomena atau gejala sosial secara lebih objektif dengan cara memperoleh gambaran yang lengkap tentang fenomena yang dikaji (Denzin, N.K, \& Lincoln, 1994). Penelitian kualitatif berangkat dari sebuah kasus tertentu yang ada pada situasi sosial tertentu. Sampel dalam penelitian kualitatif disebut narasumber, atau partisipan, dan informan. Pada penelitian kualitatif, peneliti melakukan observasi dan wawancara kepada orang-orang yang dipandang paling paham akan situasi sosial tersebut (Moha \& sudrajat, 2019; Sugiono, 2010; Suwendra, 2018).

Lokasi penelitian ini dilakukan di Pusat Informasi Konseling Remaja (PIK-R) jalur masyarakat dan jalur pendidikan sesuai kriteria yang diperlukan serta memiliki konselor sebaya bersertifikat yang didapatkan dari pelatihan konselor sebaya. PIK-R tersebut diantaranya ialah PIK-R Widiagama, PIK-R Palapa, PIK-R Mahakam Borneo, dan PIK-R Pelita Hati di kota Samarinda. Penelitian ini peneliti mengambil konselor sebaya sebagai subjek penelitian dalam upaya pencegahan perilaku seks pranikah. Wawancara adalah teknik pengumpulan data dengan cara bertatap muka dengan orang yang hendak diteliti kemudian menanyakan beberapa pertanyaan dengan tujuan untuk menggali informasi serta mendapatkan keterangan langsung dari orang yang diteliti. Bentuk wawancara yang digunakan dalam penelitian adalah wawancara semi terstruktur. Alasan menggunakan bentuk wawancara model ini adalah karena ciri-ciri dari wawancara semi-terstruktur adalah pertanyaan terbuka namun ada batasan tema dan alur pembicaraan, kecepatan wawancara dapat diprediksi, fleksibel tetapi terkontrol, ada pedoman wawancara yang dijadikan patokan dalam alur, urutan dan penggunaan kata, dan tujuan wawancara adalah untuk memahami suatu fenomena (Creswell, 2014). Dengan pertanyaan kunci adalah bagaimana upaya konselor sebaya dalam mencegah perilaku seks pranikah dikalangan remaja di Kota Samarinda?

Teknik analisis data mengelompokan data berdasarkan variabel dan jenis responden. Analisis data yang digunakan oleh penulis menggunakan analisis model Miles dan Huberman yang menggunakan analisis model alir yang dilakukan secara interaktif dan berlangsung secara terus menrus sampai selesai. Langkah dalam analisis data ini adalah pengumpulan data, reduksi data, penyajian data dan penarikan kesimpulan (Miles \& Huberman, 1992).

\section{HASIL DAN PEMBAHASAN}

Trik dikalangan konselor sebaya bersama PIK-R memiliki sebagai upaya yang berbedabeda dalam pelaksanaan kegiatan dalam mencegah perilaku seks pranikah. Upaya-upaya yang dilakukan memiliki sasaran-sasaran yang berbeda mulai dari siswa sekolah, lingkungan tempat tinggal, serta para orang tua. Upaya pencegahan perilaku seks pranikah ini beragam dan berbeda-beda dari setiap PIK-R tergantung cara pelaksanaannya dan sasarannya.

Hasil wawancara dengan Adnan Abdul Bahri Ketua PIK Palapa Kel. KS Tubun diperoleh hasil wawancara berikut: "... untuk kegiatan konselor sebaya selalu terlibat ya, dalam upaya pencegahan perilaku seks pranikah itu. Karna kita memang memilih orang-orang yang sudah mendapatkan pelatihan dari pendidik sebaya, dan konselor sebaya apalagi untuk mencapai itu kan pasti melewati proses yang lama dan pasti mereka sudah tau bagaimana caranya memberikan edukasi untuk pencegahan seks pranikah. Kalo untuk keterlibatan sih selalu terlibat." Berikut hasil wawancara dengan Ade Alfani, Ketua PIK-R UWGM Samarinda: "untuk peran konselor sebaya sejauh ini KS kita memang selalu terlibat untuk kegiatan-kegiatan yang sifatnya informatif dan edukatif, misalnya penyuluhan kadang kita sistemnya

gantian bisa saya konselor sebaya ini menyampaikan informasi terkait Triad KRR entah itu seks bebas, pernikahan dini dan lain semacamnya. Juga konselor sebaya ini terlibat untuk program teman curhatku 
jadi nanti misalnya ada remaja atau rekan-rekan sebaya ayng punya permasalahan boleh hubungi kita melalui sosial media kita."

Trik pencegahan prilaku seks pranikah dikemas dengan berupa kegiatan-kegiatan yang menarik. Selain menciptakan kegiatan yang bersifat informatif dan edukatif juga dapat membuat para remaja tertarik. Kegiatan yang bersifat ramah remaja dan kekinian akan membuat remaja tidak malu untuk bergabung dan mengikuti kegiatan. Sehingga dengan cara itu mampu menjangkau serta memikat keikut sertaan para remaja, sebagai upaya pencegahan perilaku seks pranikah pada remaja ialah sebagai berikut:

\section{Trik dengan Penyuluhan oleh Konselor melalui PIK-R}

Penyuluhan adalah sebuah kegiatan yang biasa dilakukan oleh setiap PIK-R dalam upaya pemberian informasi dengan melibatkan orang banyak sebagai audiens. Penyuluhan dilakukan agar terjadinya penyampaian informasi yang akurat dan dapat tersampaikan kepada audiens, penyampaian informasi yang diberikan oleh narasumber secara langsung dan terbuka sehingga pendengar mampu menerima pesan dengan baik. Penyuluhan diharapkan dapat menimbulkan komunikasi antara narasumber dan audiens dimana diakhir-akhir sesi pemberian materi akan ada sesi tanya jawab yang diberikan kepada audiens bila mana ada yang ingin ditanyakan. Selain komunikasi diharapkan pelaksanaan penyuluhan terjadi penyampaian informasi kepada audiens, dimana informasi yang penting seputar remaja yang disampaikan dapat tersampaikan dengan baik dan tepat sasaran. Harapan yang terakhir adalah ada nilai-nilai edukasi yang menjadi pelajaran bagi remaja yang mengikuti penyuluhan.

Penyuluhan adalah kegiatan dimana PIK-R mendatangi organisasi PIK-R yang lain atau mendatangi sekolah-sekolah atau tempat-tempat yang terdapat remaja yang perlu menerima informasi tentang pencegahan perilaku seks pranikah. Audiens kegiatan penyuluhan sendiri bisa dari mahasiswa, siswa, orang tua dan remaja. Penyuluhan yang dilakukan oleh PIK-R UWGM pernah mengadakan khusus untuk anak jalanan, dimana tujuannya agar anak jalan juga bisa mendapatkan informasi mengenai program GenRe. Penyuluhan sendiri bertujuan agar informasi yang diberikan dapat diterima oleh banyak orang dalam satu waktu.

Teknis pelaksanaan penyuluhan biasanya menentukan tempat yang akan diadakan penyuluhan, mengantar surat izin melakukan penyuluhan, mempersiapkan segala kebutuhan perlengkapan saat melakukan penyuluhan, memepersiapkan materi yang akan disampaikan, menentukan narasumber, dan melakukan brifieng sebelum melakukan penyuluhan. Hasil wawancara dengan Ade Alfani, Ketua PIK-R UWGM Samarinda: “...tu biasa tahapan-tahapannya sih kita perizinan dulu kesekolah atau ke sasaran kita, apakah bisa kita lakukan penyuluhan disana, kalau bisa kemudian kita surati, kita kirim surat kemudian kita siapkan perlengkapan apa saja yang dibutuhkan, tuh juga biasanya dari pihak kampus juga memfasilitasi seperti misalnya proyektor itu dari kampus atau dari sekolah itu sendiri yang menyiapkan," Wawancara dengan Kristiana novitania, Koodinator Bid. Penyuluhan PIK-R UWGM Samarinda, sebagai berikut: “...seperti yang saya bilang tadi misalnya ditempat kita melakukan penyuluhan itu ada salah satu audiens yang memilki kendala atau permasalahan perlu ada tindak lanjut, nah itu biasanya diarahkan kekonselor, misalkan masalahanya sedikit rumit itu nanti bakal dirujuk ke psikolog PPKS di perjuangan tiga.

\section{Trik dengan Penguatan PIK-R (pemberian pemahaman dan pembinaan)}

Upaya pencegahan seks pranikah yang dilakukan oleh PIK-R dimulai dari hal dasar. Hal mendasar yang dilakukan oleh PIK-R ialah dengan mengkader anggota PIK-R itu sendiri. Anggota PIK-R diasah kemampuannya dalam hal memahai dan menjauhkan diri dari Triad KRR. Tujuan nya agar setiap anggota PIK-R mampu menjadi komponen dalam menjadi remaja yang sehat dan berencana juga menjaga teman sebaya dilingkungannya masing-masing.

Upaya pembentukan komponen remaja sehat, terencana dan terbebas dari perilaku seks pranikah dapat berupa pemberian pemahaman kepada anggota PIK-R. Pemberian pemahaman ini bisa berupa menanamkan pemahaman materi kepada anggota PIK-R. Materi biasanya diberikan pada awal mereka bergabung didalam PIK-R. PIK-R biasanya melakukan pengkaderan 
pada saat penerimaan anggota. Disitulah pemahaman itu diberikan dan terus berkesinambungan selama mereka bergabung di PIK-R. Wawancara dengan Adnan Abdul Bahri, Ketua PIK Palapa Kel. KS Tubun; “...kami memberikan untuk diawal memberikan materi-materi edukasi, terus kalau anggota kami selalu mengingatkan juga akan bahaya-bahaya seks pranikah, terus kami juga biasa memberikan kegiatan-kegiatan yang membuat mereka paham dan kegiatan-kegiatan yang bagus, maksudnya agar mereka terhindar dari perilaku-perilaku yang tidak baik."

Pemberian pemahaman kepada anggota PIK-R ini sangat penting dilakukan untuk membentuk sebuah kelompok remaja yang memiliki keyakinan akan keutamaan kesehatan reproduksi remaja. remaja yang memiliki pemahaman yangn kuat dapat dengan mudah menjaga diri meraka. Selain itu juga remaja yang sehat dan cerdas dapat dngan mempengaruhi teman sebaya dilingkungan mereka sehingga tujuan pembentukan remaja yang sehat dan terencana yang terbebas dari perilaku seks pranikah pun dapat terwujud. Wawancara dengan Jodi Palwagunan, Ketua PIK-R Mahakam Borneo, Kec. Palaran: “...pemahaman itu lebih dari segalanya yang menurut saya jadi, kan gak mungkin kalau dia memberikan informasi tentang seks pranikah tapi dia sendiri tidak paham, jangan sampai seperti itu kan segala hal harus dimulai dari diri kita, sebelum kita sampaikan ke orang lain kita harus paham dulu lebih ke pemahaman tentang seks pranikah sih."

Pemahaman yang diberikan kepada anggota PIK-R adalah upaya dalam menjaga setiap anggota agar terhindar dari perilaku seks pranikah dan perilaku menyimpang lainnya. Perilaku yang sehat akan membuat remaja menjadi remaja yang aktif serta produktif. Remaja aktif dan produktif adalah komponen penting dalam membentuk sebuah kelompok remaja yang menyeru kepada perilaku yang sehat.

Adapun kegiatan lain yang dilakukan PIK-R yaitu berupa pemberian materi pada anggota PIK-R berupa pemberian materi. Wawancara dengan Nurul Kamaria, Ketua PIK-R Pelita Hati, IAIN Samarinda: ..."kami PIK-R pelita hati punya proker yaitu ORGAN (Obrolan GenRe Kekinian) itu semacam pemberian penyampaian materi tentang GenRe yang kami berikan ke anggota-anggota PIK-R, biasanya kami mengundang pemateri dari luar tapi biasanya juga ada demisioner yang menjadi pematerinya"

Pemberian pemahaman juga bisa diberikan berupa sharing dan berdiskusi antar sesama anggota PIK-R. Kegiatan sharing dan berdiskusi menjadi sebuah upaya pemberian pemahaman dengan dikemas secara menarik. Hal ini bertujuan untuk menarik minat dan mempermudah dalam memahami materi yang ada serta memperkuat ingatan serta pemahaman.

Pembinaan merupakan bimbingan yang diberikan oleh PIK-R yang aktif dan sudah lama terbentuk kepada kelompok remaja atau organisasi PIK-R yang baru dibentuk. Pembinaan dilakukan agar PIK-R yang baru terbentuk dapat menjalankan program kegiatan sebagai mana mestinya. Pembinaan ini dilakukan dengan harapan bahwa dengan adanya pembinaan maka PIK-R yang baru terbentuk akan mudah untuk menjalankan program kegiatan. Pembinaan ini juga menjadi upaya pencegahan perilaku seks pranikah pada remaja yang terlibat dalam anggota PIK-R yang baru terbentuk.

PIK-R yang baru terbentuk biasanya terdapat disekolah-sekolah yang baru berinisiatif untuk mendirikan organisasi PIK-R. Selain itu juga biasanya PIK-R yang baru terbentuk didirikan disekitar lingkungan masyarakat yang dimana wilayah itu baru terjamah akan program kampung KB (hasil wawancara dengan Riska Cahya Ningrum, Konselor Sebaya PIK-R Palapa Kel. KS tubun).

Disinilah peran PIK-R yang telah lebih dahulu aktif dalam menjalankan organisasi untuk dapat membimbing PIK yang baru terbentuk. Pembinaan pun dilakukan melihat apa bila pihak pengurus PIK-R meminta untuk dilakukannya pembinaan. Tetapi bisa juga pembinaan dilakukan dari inisiatif PIK-R itu sendiri ketika PIK-R yang lain terlihat sudah mulai tidak aktif dalam menjalankan program kegiatan. Pembinaa kepada PIK-R sendiri berisi tentang diskusi bersama anggota PIK-R senior, sharing-sharing terkait organisasi, pemberian materi dasar, dan lain sebagainya. Pembinaan dilakukan secara terus merus hingga anggota PIK-R yang ada didalamnya dipastikan telah memiliki pengetahuan dan pemahaman serta mampu untuk menjalankan program kegiatan secara mandiri. Dan bila PIK-R yang dibina telah aktif maka, 
mereka pun juga bisa membina PIK-R yang baru terbentuk. hasil wawancara dengan Ade Alfani, Ketua PIK-R UWGM Samarinda; “...biasanya ada PIK-R yang baru dibentuk nah, kami sosialisasi kesana." Hasil wawancara dengan Diana Yati, Konselor Sebaya PIK-R Mahakam Borneo Kec. Palaran: "...kami melakukan forum diskusi bersama teman-teman anggota PIK, dan kebetulan PIK kami telah diberi amanah untuk melakukan pembinaan kepada Pik yang ada dalam satu kecamatan. Nah kami datang kemereka dan membahas tentang semua program genre termasuk seks pranikah ini gitu." Pembinaan adalah upaya pembentukan sebuah organisasi yang berkualitas dan aktif. Diharapkan dengan pembinaan yang dilakukan PIK-R lain akan lebih aktif dalam menjalankan program kerja (Nugroho et al., 2021). Adapun penelitian sebelumnya menyatakan bahwa pembinaan juga dilakukan dalam menghadirkan sebuah organisasi PIK-R di kampus STIKES di samarinda. Pembinaan dilakukan sebanyak lima kali dalam empat bulan. Hasil dari pembinaan tersebut menunjukan bahwa terjadi peningkatan pengetahuan pada anggota dan pengurus PIKR.

\section{Trik dengan Sosialisasi Kepada Remaja}

Kegiatan sosialisasi yang dilakukan PIK-R adalah berupa kegiatan yang terjun langsung mendatangi lingkungan remaja. Kegiatan tersebut dimaksudkan untuk memberikan informasi dilingkungan remaja itu sendiri sehingga terjadi sebuah komunikasi antar kelompok remaja dengan anggota PIK-R. Objek sasaran dari kegiatan sosialisasi itu sendiri beragam tergantung masing-masing PIK-R yang melaksanakannya. Objek sasaran mulai dari anak jalanan, komunitas motor, remaja-remaja ditempat umum seperti taman, lingkungan masyarakat dan sebagainya. Hasil wawancara dengan Diana Yati, Konselor Sebaya PIK-R Mahakam Borneo Kec. Palaran: "...jadi kalo di widiagama kami juga ada program yang namanya "Japri", Japri itu jelajah reproduksi masa kini, dimana kami mendatangi tempat-tempat yang emang umum untuk mengetahui seberapa paham remaja itu tentang kesehatan reproduksi, tentang bagaimana sih upaya-upaya mereka tentang mencegah perilaku seks sebelum menikah, baru kami berdikusi, mengedukasi mereka tentang upaya-upaya yang dapat mereka lakukan."

Sosialisasi yang dilakukan dimaksudkan untuk melihat langsung kondisi para remaja dilingkungan sekitar, guna memberikan edukasi secara langsung ditempat-tempat yang biasa dikunjungi remaja. Kelompok-kelompok remaja yang tergabung dalam berbagai komunitas atau anak jalanan tentunya jarang sekali menerima informasi tentang bahaya-bahaya perilaku seks pranikah. Kominitas anak motor dan anak jalanan yang aktifitas kesehariannya jauh dari bimbingan edukasi membuat mereka rentan terjerumus akan perilaku-perilaku yang tidak sehat. PIK-R berperan untuk mesosialisasikan gerakan komunikasi, informasi, dan edukasi kepada remaja.

Kegiatan sosialisasi juga dikemas dengan kegiatan yang menarik seperti yang dilakukan PIK-R Pelita Hati dan PIK-R Palapa. Dimana dalam kegiatan sosialisasi mereka menggunakan permainan atau games sebagai alat bantu memberikan edukasi kepada remaja, permainan tersebut bernama GenRe KIT. GenRe KIT sendiri adalah permainan yang disediakan BKKBN sebagai fasilitas remaja GenRe dalam memberikan edukasi terkait dengan permasalahan remaja, kasus-kasus lingkungan serta pengetahuan tentang alat reproduksi. Riska Cahya Ningrum, Konselor Sebaya PIK-R Palapa Kel. KS tubun: “...kalau saya lebih mengedukasi sih, mengedukasi lewat kan, kami punya juga permainan GenRe KIT juga kan jadi, saya memperkenalkan terlebih dahulu permainan itu kepada remaja yang hendak bermain. Kan, dipermainan itu juga ada permasalahanpermasalahan remaja, permasalahan kita semuaada dipermainan itu, saya mengajak para remaja itu untuk berfikir dalam permainan itu."

\section{Trik dengan Sosialisasi pada orang tua remaja}

Upaya yang dilakukan PIK-R bukan hanya memberikan pencegahan kepada para remaja tetapi juga menyasar orang tua remaja. PIK-R melakukan sosialisasi kepada orang tua dilingkungan sekitar akan bahaya perilaku seks pranikah pada remaja. hal ini dimaksudkan agar orang tua yang memiliki remaja lebih aktif dalam memperhatikan anak mereka dari pergaulan. 
Upaya ini dilakukan agar orang tua yang memililiki anak remaja juga berperan aktif dalam mencegah perilaku seks pranikah. Diana Yati, Konselor Sebaya PIK-R Mahakam Borneo Kec. Palaran: "...yang pasti kita selalu mengadakan kumpul-kumpul, jadi kumpul-kumpul itu kita kasih informasi bukan hanya kepada remajanya melainkan juga kepada orang tua remajanya dan bekerja sama dengan rekan-rekan yang ada dipalaran. Dan disitu kita mempaparkan tentang bahaya si seks pranikah itu jadi biar mereka para orang tua juga tau GenRe itu apa, seks pranikah itu apa bahayanya apa jadi lebih ke sering-sering mengadakan perkumpulan sehingga mereka tahu apa-apa saja yang diperbolehkan dan mengapa seks pranikah itu tidak boleh dilakukan."

PIK-R melakukan sosialisasi kepada orang tua yang ada dilingkungan sekitar dengan membuat kegiatan-kegiatan yang melibatkan orang tua serta remaja-remaja. Seperti halnya yang dilakukan PIK-R Palapa. Mereka membuat kegiatan keagaman dengan mengundang orang tua remaja. Tujuannya adalah agar orang tua remaja berkumpul disatu tempat sehingga mempermudah pemberian edukasi kepada orang tua. Diana Yati, Konselor Sebaya PIK-R Mahakam Borneo Kec. Palaran: “...malam hari kita ada kegiatan selamatan antar warga dilingkungan terus, kami disitu memberikan kayak masukan atau penyampaian-penyampaian tentang seks pranikah. Yang diundang dalam selamatan itu orang tua dan remaja-remaja yang ada dilingkungan RT."

Kegiatan tersebut diisi dengan pembacaan dzikir, pemberian informasi dan edukasi, dan makan-makan bersama. Kegiatan ini dilakukan rutin sebulan sekali. Karena di dalam program PIK-R Palapa ada dijalankan arisan bulanan sehingga setiap akan melakukan goncangan arisan akan diadakan acara tersebut.

\section{Trik Memanfaatkan Media Sosial dalam kampanye dan dokumentasi}

Upaya yang dilakukan dalam pencegahan perilaku seks pranikah dikalangan remaja bukan hanya dilakukan dalam bentuk kegiatan tetapi juga dilakukan melalui media masa. Melihat teknologi media sosial yang hampir semua generasi milenial menggunakannya sehingga menjadi sebuah wadah dalam sebuah promosian program GenRe. PIK-R bisa dengan mudah menebarkan informasi dan edukasi menggunakan sosial media kepada remaja. Wawancara kepada Nabila uliyana syahada, Koordinator Bid, Wirausaha, PIK-R Palapa: "kalau untuk media sih ada instagram kami juga baru buat blog dan isinya masih mengenai PIK-R kami, dan Facebook juga ada, kalu untuk yang lain sih belum baru berupa pamlet-pamplet dan banner sih" "biasanya sih, poster-poster aja. Media online nya sih Instagram. Namanya PIK-R Mahakam Borneo. Biasanya kami ngeshare tentang permasalahanpermasalahan remaja, ada juga tentang hari-hari besar."

Sosial media yang digunakan bisa melalui Youtube, Instagram, Facebook dan berbagai macam media lainnya. Adapun nama akun instagran mereka ada @pik_mahakamborneo, @pikremaja_pelitahati, @pikr_uwgmsamarinda, @pik.palapa dan akun youtube mereka ada PIKR Pelita Hati dan PIKRUWGM samarinda. PIK-R juga sering diundang untuk menyampaikan informasi seputar GenRe dikantor penyiaran radio RRI di Kota Samarinda. Sosial media dimanfaatkan sebagai alat menebarkan informasi tentang perilaku seks pranikah pada kalangan remaja karena ke efektifannya dalam menebarkan informasi. Hampir semua PIK-R memiliki sosial media sendiri dalam menebarkan informasi. Wawancara kepada Kristiana novitania, Koodinator Bid. Penyuluhan PIK-R UWGM Samarinda: “...untuk media sendiri selain dari kita melakukan penyuluhan itu kita menggunakan Instagram PIK-R sendiri, karna sedang masa pandemi covid jadi, kita menggunakan Youtube juga, jadi apa yang di upload di Instagram itu di upload juga di Youtube."

Penyebaran informasi melalui sosial media ini dibentuk menjadi program-program kegiatan. Program tersebut bernama "PENYOL" alias Penyuluhan online. PIK-R yang membentuk program Penyol adalah PIK-R UWGM. Penyuluhan online dibentuk dikarenakan masa pandemi, sehingga mengharuskan mereka untuk mengadakan kegiatan yang tidak membuat kerumunan.

Dalam mencegah perilaku seks pranikah pada remaja dilaksanakan dengan berbagai macam kegiatan-kegiatan dan program kerja, dapat melibatkan orang tua (Dela et al., 2021). PIK$\mathrm{R}$ merancang sebuah program kerja yang menarik dan dapat melibatkan para remaja dalam kegiatan yang dibuat. Tujuan nya agar remaja mendapatkan edukasi dan informasi yang 
berkaitan dengan kesehatan reproduksi sehingga dapat menimbulkan mineside pada remaja akan bahaya dari seks pranikah (Adawiyah \& Winarti, 2021).

Sasaran yang dituju oleh PIK-R adalah pertama yaitu anggota yang tergabung dalam PIK$\mathrm{R}$ itu sendiri. Anggota PIK-R diberikan pembelajaran serta pemahaman agar mereka memiliki pandangan akan pentingnya mempersiapkan kehidupan berkeluarga yang matang serta diberikan informasi-informasi tentang program GenRe itu sendiri. Hal ini dimaksudkan untuk menjadikan para remaja yang tergabung dalam PIK-R menjadi komponen remaja yang dapat menebarkan informasi dan edukasi kepada remaja yang lain.

Hasil data yang diperoleh dari empat PIK-R menunjukan bahwa mereka memiliki setrategi yang sama dalam membentuk remaja yang terencana, sehat dan terjauhkan dari perilaku seks pranikah. Strategi itu berupa sharing dan diskusi yang dilakukan bersama seluruh anggota PIKR. Adapun penjabaran sharing dan dikusi sebagai berikut:

Sharing yang dilakukan keempat PIK-R adalah berupa pemberian informasi terkait dengan program GenRe. Informasi yang diberikan adalah materi-materi dasar seperti Pendewasaan Usia Perkawinan (PUP), Seksualitas, Bonus Demografi, HIV dan AIDS, Bahaya Narkoba dan sebagainya (Syahputra, 2015). Sharing ini dilaksanakan oleh PIK-R pada saat awal penerimaan anggota baru, PIK-R mengkader anggotanya pada awal mereka bergabung di PIK-R sebagai penanaman pemahaman kepada anggota akan tujuan mereka bergabung ke PIK-R.

Sharing adalah upaya pemberian ilmu kepada anggota PIK-R karena setiap anggota PIK-R adalah remaja-remaja yang mempromosikan tentang kesehatan remaja, perilaku sehat dan remaja yang mendidik teman sebaya, sehingga penanaman ilmu sangat penting bagi anggota PIK-R. Sharing informasi ini dilakukan secara berkesinambungan selama mereka para anggota tergabung didalam PIK-R, hasil penelitian menemukan ada hubungan peran pendidik sebaya dengan pemanfaatan PIK-R pada remaja (Fadzilla \& Djannah, 2019).

Media online adalah media yang dimanfaatkan dalam menyebarkan informasi dan edukasi. Media online juga sebagai fasilitas yang dapat digunakan untuk menyediakan layanan online yang dilakukan PIK-R UWGM dalam memberikan layanan konseling kepada remaja. seluruh PIK-R memiliki media sosial seperti Instagram, Youtube (Salehudin, 2020), Facebook dan lain sebagainya (Ho et al., 2016; Indrawati et al., 2017). Data yang diperoleh bahwa PIK-R menggunakan media sosial untuk menebarkan informasi dan edukasi terkait dengan program GenRe juga pencegahan perilaku seks pranikah dan memperingati hari-hari besar.

Media online digunakan dalam menebarkan edukasi pada remaja. melihat dari hampir semua remaja menggunakan sosial media untuk berkomunikasi dan berekspresi. Sehingga PIK-R melalui media sosial berupaya untuk menebarkan informasi-informasi dan edukasi agar mampu menyasar para remaja secara luas (Cahyono, n.d.; Carlina, 2017).

\section{Trik Penyuluhan dan Sosialisasi}

Data yang diperoleh dari keempat PIK-R yang diteliti bahwa penyuluhan merupakan upaya yang dilakukan oleh setiap PIK-R dalam memberikan edukasi, informasi, dan mencegah perilaku seks pranikah pada remaja. Penyuluhan merupakan kegiatan yang cukup sering dilakukan oleh PIK-R karena penyuluhan adalah kegiatan yang sangat efektif dalam menyebarkan informasi. Dimana remaja berkumpul dan bersama mendengarkan materi-materi yang diberikan oleh narasumber. Penyuluhan juga bisa dikatakan kegiatan yang menarik dan edukatif.

Penyuluhan yang dikemas dengan kegiatan-kegiatan yang menarik dapat meningkatkan pengetahuan remaja terhadap kesehatan reproduksinya. Remaja yang memiliki pengetahuan cenderung menjadi lebih meningkat kesadaran diri untuk menjaga kesehatan. Seperti hasil penelitian yang dilakukan sebelumnya menunjukan bahwa remaja cenderung mendapatkan perubahan pengetahuan yang drastis akan alat reproduksi mereka setelah mengikuti penyuluhan kesehatan reproduksi remaja (Afifah, 2018).

Sasaran yang menjadi target PIK-R dalam melaksanakan penyuluhan adalah mulai dari remaja tingkat SMP, pada siswa SMA (Fatmariza, 2019) dan Mahasiswa. Lokasi penyuluhan 
adalah lingkungan remaja, sekolah-sekolah, dan kampus-kampus. Dan juga tidak hanya di dalam daerah tetapi juga di luar daerah. Materi yang disampaikan ketika melakukan penyuluhan biasanya seputar GenRe yaitu meliputi, kesehatan reproduksi remaja, pendewasaan usia perkawinan, inveksi menular seksual, Napza dan lain sebagainya.

Penyuluhan dilakukan bisa sampai luar daerah, data yang diperoleh menunjukan penyuluhan pernah dilakukan di kota Tenggarong, Paser, Berau, dan Tarakan. Ini menunjukan bahwa penyuluhan tidak hanya dilakukan pada remaja sekitar bahkan juga sampai remaja yang ada diluar daerah. Melihat hal ini totalitas PIK-R dalam memberikan informasi dan edukasi dalam mencegah perilaku seks pranikah pada remaja sangat maksimal. Upaya penyuluhan ini juga dilakukan PIK-R lain. Menurut hasil penelitian yang telah dilakukan sebelumnya bahwa dalam upaya implementasi ekstrakulikuler PIK-R dalam mencegah kenakalan remaja adalah dengan melakukan penyuluhan dan sosialisasi. Terkait dengan materi yang disampaikan meliputi bahaya merokok dan dampak berpacaran yang tidak sehat (Silfiana \& Setyowati, 2017). Dapat dipahami bahwa penyuluhan menjadi upaya yang dilakukan setiap PIK-R dalam melaksanakan program kerja.

Sosialisasi memiliki teknis yang sama dengan penyuluhan hanya saja media yang digunakan untuk menyampaikan informasi berbeda. Sosialisasi menggunakan media GenRe KIT dalam memberikan edukasi dan informasi. GenRe KIT merupakan sebuah permainan yang berisi ular tangga, monopoli dan clemek bergambar alat reproduksi manusia. Permainan ini sifatnya mengajak remaja untuk bermain sambil belajar karna dalam permainan itu remaja diajak untuk berfikir bagaimana menanggapi, besikap, dan berargumen, pada sebuah kasus-kasus dan permasalahan para remaja.

Media GenRe KIT sendiri berisi banyak kasus-kasus yang mengkaitkan dengan Triad KRR (tiga permasalahan kesehatan reproduksi remaja), dalam permainan tersebut remaja dihadapkan pada sebuah kasus aborsi, pernikahan dini, kehamilan tidak diinginkan, infeksi menular seksual, dan sebagainya. Sehingga media GenRe KIT ini benar-benar efektif dalam mencegah perilaku seks pranikah. Data yang diperoleh bahwa setiap PIK-R memanfaatkan permainan tersebut dalam melaksanakan sosialisasi pada remaja. Permainan GenRe KIT digunakan oleh setiap PIK$\mathrm{R}$ yang ada di kota Samarinda sebagai fasislitas dalam memberikan edukasi saat melakukan kegiatan sosialisasi. Setiap PIK-R dapat meminjam permainan tersebut yang telah disediakan oleh kantor BKKBN. Permainan GenRe KIT sangat efektif dalam mengedukasi remaja. Hasil penelitian sebelumnya menunjukan bahwa setelah mermainkan permainan GenRe KIT remaja memiliki peningkatan pengetahuan akan kesehatan reproduksi sebesar 25\% (Mahfudzoh, 2020). Ini menunjukan bahwa permainan GenRe KIT sangat efektif dalam melakukan sosialisasi.

Sosialisasi yang dilakukan pada orang tua remaja merupakan sebuah bentuk upaya dalam mencegah perilaku seks pranikah pada remaja. Diharapkan dengan adanya kerja sama antara PIK-R dan BKR dapat berdampak besar bagi pencegahan perilaku seks pranikah pada remaja. Dan juga orang tua dapat berperan aktif juga berkesinambungan dalam mendidik remajanya (Darmawan, 2018; Haryani et al., 2015). Buku yang disusun BKKBN menjelaskan bahwa peran orang tua sebagai pendidik bagi remaja sangat dibutuhkan.

Uraian diatas dapat disimpulkan bahwa upaya mencegah perilaku seks pranikah ialah dengan bersosialisasi pada remaja dan orang tua remaja. Sosialisasi dilakukan dengan menggunakan media GenRe KIT serta dalam bentuk kegiatan yang dapat melibatkan orang tua remaja. Kegiatan tersebut berupa bekerjasama antar PIK-R dan Bina Keluarga Remaja setempat dengan megadakan kegiatan yang positif.

\section{KESIMPULAN}

Fokus penelitian ini adalah untuk mengetahui trik konselor sebaya dan upaya mencegah perilaku seks pranikah pada remaja maka penelitian hanya fokus mengali upaya tersebut. Temuan penelitian adalah bahwa PIK-R memiliki media yaitu GenRe KIT dimana media tersebut sangat efektif dalam memberikan pengetahuan pada remaja mengenai kesehatan alat reproduksi mereka. Hasil penelitian pada upaya yang dilakukan beberapa trik konselor Sebaya bersama PIK- 
$\mathrm{R}$ dalam upaya mencegah perilaku seks pranikah yaitu diantaranya; 1) Trik dengan Penyuluhan oleh konselor sebaya ke lingkungan remaja dan ke sekolah-sekolah, 2) Trik dengan Penguatan PIK-R (pemberian pemahaman dan pembinaan) pemahaman kepada anggota PIK-R melalui sharing materi dan diskusi serta pembinaan kepada PIK-R yang baru dibentuk, 3) Trik dengan Sosialisasi Kepada Remaja 4). Trik dengan sosialisasi kepada orang tua 5). Trik Memanfaatkan Media Sosial dalam kampanye dan dokumentasi, dan 6). Trik Penyuluhan dan Sosialisasi. Terjun langsung ke lingkungan remaja dengan media GenRe KIT dan melakukan sosialisasi kepada orang tua remaja dan bekerjasama dengan BKR (Bina Keluarga Remaja).

\section{DAFTAR PUSTAKA}

Adawiyah, S., \& Winarti, Y. (2021). Hubungan Usia dan Jenis Kelamin dengan Inisasi Seks Pranikah Pada Remaja di SMK Istiqomah Muhammadiyah 4 Samarinda. Borneo Student Research, 2(2), 1202-1208.

Afifah, T. (2018). Efektifitas Penyuluhan Kesehatan Reproduksi Remaja Dengan Pemberian Modul Terhadap Perubahan Pengetahuan Remaja. Jurnal Manajement Kesehatan Yayasan RS.Dr.Soetomo, 4.

Budiyono, A., \& Faishol, L. (2020). Peran Pusat Informasi Konseling Remaja (PIK-R) Dalam Meningkatkan Kemampuan Kontrol Diri Perilaku Menyimpang Remaja. Jurnal Bimbingan Konseling Pendidikan Islam Coution : Journal of Counseling and Education, 1(2), 50-59.

Cahyono, G. H. (n.d.). Integrasi Pengajaran: Menggunakan Jaringan Media Sosial Untuk Mengarahkan Para Siswa. Forum Diklat, 06(4).

Carlina, G. (2017). PR Crisis Melalui Media Sosial. Jurnal Komunikasi, 9(1), 81-86.

Creswell, J. W. (2014). Research Design: Qualitative, Quantitative and Mixed Methods Approaches (Fourth Edi). SAGE Publications, Inc.

Darmawan, F. H. (2018). Gaya Hidup dan Peran Orang Tua Dalam Perilaku Seks Bebas pada Remaja di SMK Pasundan Putra Cimahi. Jurnal Ilmiah Dan Kesehatan’ Aisyiyah, 3(2), 7687.

Dela, V. L., Arrasyid, H., \& Widanun, C. (2021). Upaya Orangtua Dalam Mencegah Perilaku Seks Pranikah Sesuai Dengan Ajaran Islam Dikelurahan Wek IV Kampung Jawa Kecematan Padangsidimpuan Utara. Ristekdik (Jurnal Bimbingan Dan Konseling), 6(1), 40-46.

Denzin, N.K, \& Lincoln, Y. . (1994). Handbook of Qualitative Research. SAGE Publications, Inc. Fadzilla, V., \& Djannah, S. N. (2019). Faktor-Faktor Yang Berhubungan Dengan Pemanfaatan Pusat Informasi Dan Konseling Remaja (PIK-R) Pada Remaja Di SMA N 1 Sanden. Jurnal Cakrawala Promkes, 1(1), 9. https://doi.org/10.12928/promkes.v1i1.291

Fatmariza, E. (2019). Efektivitas Pusat Informasi Konseling Remaja ( PIK-R ) Di SMAN 1 Selong Tahun Pelajaran. Jurnal Konseling Pendidikan Elina, 3(2), 73-89.

Haryani, D. S., Wahyuningsih, W., \& Haryani, K. (2015). Peran Orang Tua Berhubungan dengan Perilaku Seksual Pra Nikah Remaja di SMKN 1 Sedayu. Jurnal Ners Dan Kebidanan Indonesia (JNKI), 3(3), 140. https://doi.org/10.21927/jnki.2015.3(3).140-144

Ho, J., Lee, E., Lee, J., Rang, T., \& Sung, Y. (2016). The role of narcissism in self-promotion on Instagram. PAID, 101, 22-25. https://doi.org/10.1016/j.paid.2016.05.042

Indrawati, K. ayu P., Sudiarta, I. N., \& Suardana, I. W. (2017). Efektivitas Iklan Melalui Media Sosial Facebook Dan Instagram Sebagai Salah Satu Strategi Pemasaran Di Krisna Oleh-Oleh Khas Bali. Jurnal Analisis Pariwisata, 17(2), 78-83.

Irmawaty, L. (2013). Perilaku Seksual Pranikah Pada Mahasiswa. Jurnal Kesehatan Masyarakat, 9(1), 44-52.

Kurwiyah, N. (2019). Peran Konselor Sebaya Terhadap Upaya Berhenti Merokok Di SMP 219 Jakarta. Indonesian Journal of Nursing Sciences and Practice, 1(2), 27-33.

Kusumawaty, I., Yunike, Y., Elviani, Y., \& Harmiyati, L. (2020). Penguatan Kapasitas Konselor Sebaya di Sekolah. Journal of Community Engagement in Health, 3(2), 140-146. https://doi.org/10.30994/jceh.v3i2.52 
Lestari, I. A., Fibriana, A. I., \& Prameswari, G. N. (2014). Faktor-Faktor Yang Berhubungan Dengan Perilaku Seks Pranikah Pada Mahasiswa Unnes. Unnes Journal of Public Health (UJPH), 3(4), 27-38. https://doi.org/10.15294/ujph.v3i4.3903

Mahfudzoh, D. (2020). Peningkatan Pemahaman Siswa Tentang Resiko Perilaku Seksual Pranikah Melalui Layanan Bimbingan Klasikal Dengan Media Genre Kit. Empati-Jurnal Bimbingan Dan Konseling, 7(1), 23-35.

Miles, M. B., \& Huberman, A. M. (1992). Analisis Data Kualitatif. UI Press.

Moha, I., \& sudrajat, D. (2019). Resume Ragam Penelitian Kualitatif. https://doi.org/10.31227/osf.io/wtncz

Nugroho, Y. T., Sari, R. E., \& Meckarische, A. A. (2021). Efektivitas Pusat Informasi Konseling Remaja (PIK-R); Studi Kualitatif Dengan Teknik Most Significant Change (MSC). Jurnal Ilmu Dan Teknologi Kesehatan Terpadu (JITKT), 1(1), 1-12.

Nurochim, N. (2021). Analisis SWOT (strengths, weaknesses, opportunities, threats) pusat informasi dan konseling remaja (PIK-Remaja). Jurnal Konseling Dan Pendidikan, 9(1), 11. https://doi.org/10.29210/151800

Nursal, D. G. A., Mardatillah, M., Desirman Pratiwi, S., \& Rahmadona, S. (2020). Pemanfataan Pusat Informasi Dan Konseling Remaja (PIK-R) Oleh Remaja Di SMK Kota Padang Tahun 2020. IAKMI Jurnal Kesehatan Masyarakat Indonesia, 1(3).

Rohmah, N., Nurrahmawati, A., \& H, P. T. (2015). Hubungan Sikap Dan Pola Komunikasi Orang Tua Dengan Perilaku Seks Pranikah Pada Siswa Sma Di Kota Samarinda Tahun 2015. Kesmas Wigama; Jurnal Kesehatan Masyarakat, 1(2), 74-82.

Rosdarni, Dasuki, D., \& Waluyo, S. D. (2015). Pengaruh Faktor Personal terhadap Perilaku Seksual Pranikah pada Remaja. JKesmas: Jurnal Kesehatan Masyarakat Nasional, 9(3), 214-221.

Salehudin, M. (2020). Literasi Digital Media Sosial Youtube Anak Usia Dini/ Digital Social Media Youtube Early Childhood. Jurnal Ilmiah Potensia, 5(2), 106-115.

Sarmin. (2017). Konselor Sebaya: Pemberdayaan Teman Sebaya Dalam Sekolah Guna Menanggulangi Pengaruh Negatif Lingkungan. BRILLIANT: Jurnal Riset Dan Konseptual, 2(1), 102-112.

Silfiana, L., \& Setyowati, R. N. (2017). Peran Pengurus Dan Pembina Ekstrakurikuler Pusat Informasi Dan Konseling Remaja (PIK-R) Dalam Mencegah Kenakalan Remaja Di SMA Pawiyatan Daha Kediri. Kajian Moral Dan Kewarganegaraan, 5(02), 161-175.

Sugiono. (2010). Metode Penelitian Pendidikan; Pendekatan Kuantitatif, Kualitatif dan R\&D (cetakan ke). Alfabeta, CV.

Suparmi, S., \& Isfandari, S. (2016). Peran Teman Sebaya terhadap Perilaku Seksual Pranikah pada Remaja Laki-Laki dan Perempuan di Indonesia. Buletin Penelitian Kesehatan, 44(2), 139146. https://doi.org/10.22435/bpk.v44i2.5457.139-146

Suwendra, I. W. (2018). Metodologi Penelitian Kualitatif dalam Ilmu Sosial, Pendidikan, Kebudayaan, dan Keagamaan. In NilaCakra Publishing House, Bandung. NILACAKRA.

Syahputra, R. (2015). Peran Dinas Kesehatan Kota Dalam Pencegahan Penyakit HIV/AIDS di Kota Samarinda. EJournal Ilmu Pemerintahan, 1-15. http://ejournal.ip.fisipunmul.ac.id/site/wp-content/uploads/2015/11/eJournal (11-17-15-03-06-23).pdf

Trisnani, R. P., \& Wardani, S. Y. (2018). Peran Konselor Sebaya Untuk Mereduksi Kecanduan Game Online Pada Anak. Dialektika Masyarakat: Jurnal Sosiolog, 2(2), 72-80.

Wibowo, M., Gustina, E., \& Hastuti, S. K. W. (2020). Upaya Meningkatkan Pengetahuan Pendidik Sebaya Pusat Informasi Konseling Remaja Tentang Kesehatan Reproduksi. Jurnal Pengabdian Dan Pemberdayaan Masyarakat, 4(2), 187-193.

Yudia, S. M., Cahyo, K., \& Kusumawati, A. (2018). Perilaku Seksual Pranikah Pada Mahasiswa Kost (Studi Kasus Pada Perguruan Tinggi "X” Di Wilayah Jakarta Barat). Jurnal Kesehatan Masyarakat (e-Journal), 6(1), 819-825. 